О. В. Поканевич, Б. Б. Івнєв, П. І. Середа, В. І. Талько, І. А. Оверченко, I. В. Керечанин, Н. В. Ковальчук

Вищий приватний навчальний заклад “Київський медичний університет”

\title{
ОСОБЛИВОСТІ МЕТОДИКИ ВИКЛАДАННЯ ДИСЦИПЛІНИ “АНАТОМІЯ ЛЮДИНИ” СТУДЕНТАМ АНГЛОМОВНОЇ ФОРМИ НАВЧАННЯ
}

\author{
O. V. Pokanevych, B. B. Ivnev, P. I. Sereda, V. I. Talko, I. A. Overchenko, \\ I. V. Kerechanyn, N. V. Kovalchuk \\ Private Higher Educational Establishment "Kyiv Medical University”
}

\section{FEATURES OF THE METHODOLOGY OF TEACHING THE SUBJECT "HUMAN ANATOMY” TO ENGLISH SPEAKING STUDENTS}

\begin{abstract}
Мета роботи - розроблення методів покращення результату навчальної діяльності студентів англомовної форми навчання. Основна частина. Вивчення дисципліни “Анатомія людини” збігається з першим роком перебування студента-іноземця в Україні. Успіх навчальної діяльності залежить від рівня адаптації іноземного студента до нового освітнього середовища. У соціально-психологічному аспекті адаптації слід зауважити такі фактори, як релігія та гендерна політика рідної студенту країни. У значної частини студентів-першокурсників англомовної форми навчання виникають проблеми з адаптацією, що пов’язано з особистими якостями самих студентів, відсутністю навичок до самостійної навчальної діяльності, несформованістю професійного самовизначення, комунікабельності та компромісності в спілкуванні із викладачем й одногрупниками. Особливістю методики викладання базової медичної дисципліни “Анатомія людини” є необхідність оптимізації процесу викладання шляхом розробки стандартизованих контрольних форм роботи та консультування студента, тобто перехід від екстенсивно-інформаційного до інтенсивно-фундаментального навчання, яке вимагає принципової зміни навчальних технологій, перебудови взаємовідносин викладача і студента. Обов’язковим $є$ використання тестових завдань, розв'язування ситуаційних завдань, розвиток практичних навичок шляхом демонстрації органів та їх структури на муляжах.

Висновок. Навчально-виховний процес студента на етапі вивчення базової медичної дисципліни “Анатомія людини” має бути орієнтований на впровадження нових методик та інноваційних технологій, що створює умови для формування професійної компетентності майбутнього лікаря.
\end{abstract}

Ключові слова: адаптація; екстенсивно-інформаційне навчання; інтенсивно-фундаментальне навчання.

The aim of the work - the development of methods for improvement of the English speaking students' educational activities.

The main body. Discipline "Human anatomy" belongs to the first year subjects studied by foreign students. The success of the training activities depends on the level of adaptation of foreign students to their new educational environment. The peculiarity of teaching basic medical subjects "Human anatomy" is necessary to optimize the process of teaching, by developing standards of controling forms and providing consultation for the students, such as, the transformation from extensive information to intensive fundamental training. This transformation demands fundamental changes to the educational process, restructuring the relationship between the teachers and the students. It is necessary to use the test tasks, development and improvement practical skills through demonstrations of organs and their structure on moulage.

Conclusion. Thus, student's educational process at the stage of studying of basic "Human anatomy" has to be focused on implementation of new methods and innovative technologies in the educational process, which creates the conditions for formation of professional competence of future doctors.

Key words: adaptation; extensive information training; intensive fundamental training.

Вступ. Як відомо, дисципліна “Анатомія людини” є фундаментальною дисципліною усіх вищих медичних навчальних закладів $[1,2]$. Вивчення дисципліни збігається з першим роком перебування студента-іноземця в Україні. Успіх навчальної діяльності залежить від рівня адаптації іноземного студента до нового освітнього середовища.

() О. В. Поканевич, Б. Б. Івнєв, П. І. Середа та ін. 
Мета роботи - розроблення методів покращення результату навчальної діяльності студентів англомовної форми навчання.

Основна частина. У соціально-психологічному аспекті адаптації слід зауважити такий невід’ємний фактор будь-якого соціуму, як релігія. Навчаючись в одній групі, студенти різних країн можуть належати до різних релігіозних конфесій, які, на жаль, не завжди толерантно ставляться до представників інших віросповідань. 3 метою запобігання зародженню міжрелігійної ворожнечі важливим $\epsilon$ формування груп студентів 3 однаковим віросповіданням. Не менш важливою є гендерна політика рідної студенту країни, яка, як правило, відгукується у відносинах студента із протилежною статтю в групі та взагалі у навчальному закладі. Студенти чоловічої статі, особливо представники східних країн, інколи упереджено сприймають викладачажінку й навіть ворожо та неприязно реагують на зауваження, нервують при спробі викладача корегувати відповідь, різко переходять на підвищений тон у разі невідповідності отриманої та очікуваної оцінок. Студентки із східних країн соромляться відвідувати у присутності одногрупників-чоловіків заняття з навчальних дисциплін або ж зовсім не приходять на заняття, теми яких стосуються статевих органів, пояснюючи це правилами виховання та релігією. Деякі студенти-іноземці англомовної форми навчання відчувають труднощі у побутовому спілкуванні, якщо не володіють українською мовою.

Процес адаптації тривалий та не завжди успішний. У значної частини студентів-першокурсників англомовної форми навчання виникають проблеми 3 адаптацією, що пов'язано $з$ особистими якостями самих студентів, відсутністю навичок до самостійної навчальної діяльності, несформованістю професійного самовизначення, комунікабельності та компромісності в спілкуванні із викладачем й одногрупниками.

\section{Список літератури}

1. Медична освіта у світі та в Україні [Ю. В. Поляченко, В. Г. Передерій, О. П. Волосовець та ін.]. - К. : Книга плюс, 2005. - 384 с.

2. Максименко С. Д. Впровадження нових методик та інноваційних технологій у навчально-виховний процес / С. Д. Максименко, М. М. Філоненко // Наук. вісн. Нац. мед. ун-ту ім. О. О. Богомольця. - 2008. - № 2/3. C. $172-176$.
Окрім науково-педагогічної діяльності, викладачі допомагають першокурсникам пристосуватися до вимог навчального процесу без відчуття внутрішнього дискомфорту та безконфліктно існувати в колективі.

Особливістю методики викладання базової медичної дисципліни “Анатомія людини” є необхідність оптимізації процесу викладання шляхом розробки стандартизованих контрольних форм роботи та консультування студента, тобто перехід від екстенсивно-інформаційного до інтенсивно-фундаментального навчання, яке вимагає принципової зміни навчальних технологій, перебудови взаємовідносин викладача і студента $[3,4]$. Ще однією 3 принципових проблем викладання дисципліни “Анатомія людини” на інформаційному рівні полягає в тому, що у багатьох закордонних навчальних закладах використовуються інші види тестування поточного та кінцевого рівня знань, аніж ліцензований інтегрований іспит “Крок 1". Тому було поставлено за мету використання тестів формату А4 насамперед з навчальною метою.

Однією з проблем як для викладача, так і студента у викладанні та вивченні дисципліни є відсутність вологих препаратів частин та органів людського тіла. Незважаючи на якість пластикових муляжів вітчизняних та закордонних виробників анатомічних муляжів як навчального приладдя, муляжі не здатні відтворити натуральні препарати. Як результат унеможливлюється препарування як невід'ємна частина здобуття практичних навичок.

Висновок. Отже, у контексті зазначеного вище навчально-виховний процес студента на етапі вивчення базової медичної дисципліни “Анатомія людини” має бути орієнтований на впровадження нових методик та інноваційних технологій, що створює умови для формування професійної компетентності майбутнього лікаря, розвитку його творчого потенціалу, системної самостійної роботи студентів щодо оволодіння науковими знаннями.

3. Москаленко В. Ф. Про стан та шляхи удосконалення організації самостійної роботи студентів / В. Ф. Москаленко, О. П. Яворовський, Л. І. Остапюк // Медична освіта. - 2004. - № 1. - С. 10-12.

4. Волосовець О. П. Зміст і форми організації самостійної роботи студента у вищих медичних навчальних закладах IV рівня акредитації / О. П. Волосовець, Й. С. Вітенко // Медична освіта. - 2004. - № 1. - С. 5-8. 


\section{References}

1. Poliachenko, Yu.V., Perederii, V.H., Volosovets, O.P., \& Moskalenko, V.F. (2005). Medychna osvita $v$ sviti ta $v$ Ukraini [Medical education in the world and in Ukraine]. Kyiv: Knyha plius [in Ukrainian].

2. Maksymenko, S.D. (2008). Vprovadzhennia novykh metodyk ta innovatsiinykh tekhnolohii u navchalnovykhovnyi protsess [Implementation of new methods and innovative technologies in educational process training]. Nauk. visn. Nats. med. un-tu im. O.O. BohomoltsiaScientific Journal of O. Bohomolets National Medical University, 2/3, 172-176.
3. Moskalenko, V.F., Yavorovskyi, O.P., \& Ostapiuk, L.I. (2004). Pro stan ta shliakhy udoskonalennia orhanizatsii samostiinoi roboty studentiv [About the condition and ways of improving the organization of independent work of students]. Medychna osvita - Medical Education, 1, 10-12 [in Ukrainian].

4. Volosovets, O.P., \& Vitenko, Y.S. (2004) Zmist i formy orhanizatsii samostiinoi roboty studenta u vyshchykh medychnykh navchalnykh zakladakh 4 rivnia akredytatsii [The content and the form of organization of independent work of students in higher medical educational institutions of 4th level of accreditation]. Medychna osvita - Medical Education, 1, 5-8 [in Ukrainian].

Електронна адреса для листування: dr.kerechanyn@kmu.edu.ua 